\title{
Three new trixane glycosides obtained from the leaves of Jungia sellowii Less. using centrifugal partition chromatography
}

\author{
Luíse Azevedo ${ }^{1}$, Larissa Faqueti ${ }^{1}$, Marina Kritsanida ${ }^{2}$, Antonia Efstathiou ${ }^{3}$, \\ Despina Smirlis ${ }^{3}$, Gilberto C. Franchi $\mathrm{Jr}^{4}$, Grégory Genta-Jouve ${ }^{2}$, Sylvie Michel ${ }^{2}$, \\ Louis P. Sandjo ${ }^{1}$, Raphaël Grougnet ${ }^{*} 2, \S$ and Maique W. Biavatti ${ }^{*} 1, \uparrow$
}

\section{Full Research Paper}

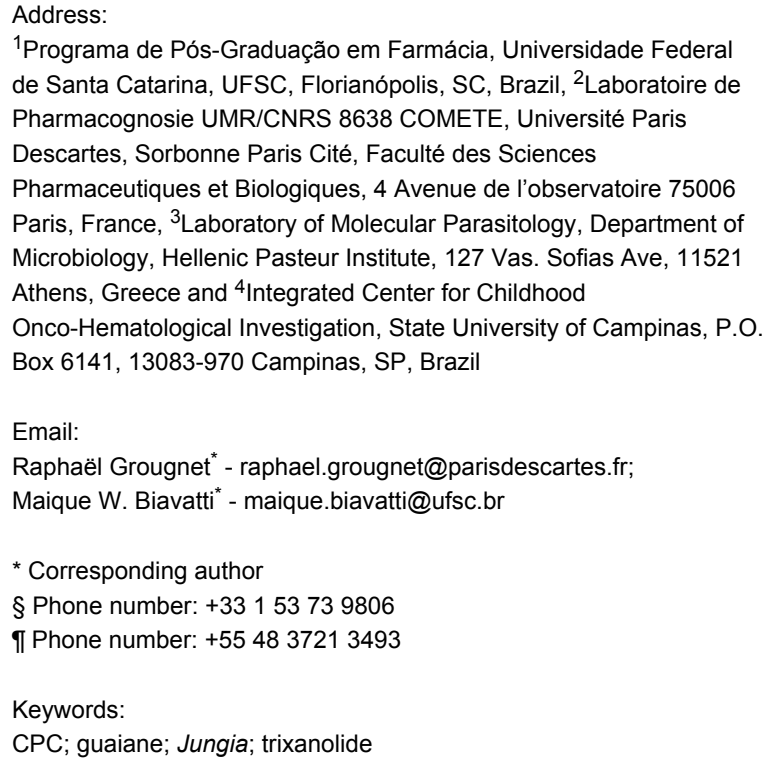

${ }^{1}$ Programa de Pós-Graduação em Farmácia, Universidade Federal de Santa Catarina, UFSC, Florianópolis, SC, Brazil, ${ }^{2}$ Laboratoire de Pharmacognosie UMR/CNRS 8638 COMETE, Université Paris Descartes, Sorbonne Paris Cité, Faculté des Sciences Pharmaceutiques et Biologiques, 4 Avenue de l'observatoire 75006 Paris, France, ${ }^{3}$ Laboratory of Molecular Parasitology, Department of Microbiology, Hellenic Pasteur Institute, 127 Vas. Sofias Ave, 11521 Athens, Greece and ${ }^{4}$ Integrated Center for Childhood Onco-Hematological Investigation, State University of Campinas, P.O. Box 6141, 13083-970 Campinas, SP, Brazil

Email:

Raphaël Grougnet ${ }^{\star}$ - raphael.grougnet@parisdescartes.fr;

Maique W. Biavatti - maique.biavatti@ufsc.br

* Corresponding author

§ Phone number: +33153739806

If Phone number: +55 4837213493

Keywords:

CPC; guaiane; Jungia; trixanolide

\author{
Beilstein J. Org. Chem. 2016, 12, 674-683. \\ doi:10.3762/bjoc. 12.68
}

Received: 08 December 2015

Accepted: 22 March 2016

Published: 12 April 2016

Associate Editor: R. Sarpong

(c) 2016 Azevedo et al; licensee Beilstein-Institut. License and terms: see end of document.

\footnotetext{
Abstract

Jungia sellowii (Asteraceae) is a shrub that grows in Southern Brazil and polar extract of its leaves presents anti-inflammatory properties. Cyperane, guaiane, nortrixane, and trixane sesquiterpene types were reported as the main metabolites in Jungia species. This work aims to describe the isolation and identification of sesquiterpenes in the leaves of $J$. sellowii using liquid-liquid partition and centrifugal partition chromatography. Thus, the crude extract of fresh leaves of $J$. sellowii was partitioned with hexane, dichloromethane, ethyl acetate and butanol, respectively. The butanol fraction was then subjected to a selected ternary system optimized for the CPC (centrifugal partition chromatography): ethyl acetate-ethanol-water $(9: 2: 10, \mathrm{v} / \mathrm{v} / \mathrm{v})$. The separation was carried out isocratically at a flow rate of $25 \mathrm{~mL} / \mathrm{min}$ at $1200 \mathrm{rpm}$, affording seven fractions A to G. TLC of fractions B, C and F displayed a single spot corresponding to three new glycosylated sesquiterpenoids. Their structures were established by using spectroscopic data in comparison to those reported in the literature. Furthermore, the isolates were evaluated for their leishmanicidal and cytotoxic effects. No cytotoxic effect was observed against the three cancer cell lines (HL60, JURKAT and REH), but compound $\mathbf{1}$ showed a
} 
weak antiprotozoal activity. Liquid-liquid partition and CPC turned to be a versatile technique of glycoside purification which is environmentally friendly and requires a limited amount of organic solvents.

\section{Introduction}

Jungia (Asteraceae) comprises shrubs, lianas and herbs, widely distributed from Central to South America, including Southern Brazil. Species such as J. paniculata and J. polita are used in South America to disinfect and cure external wounds, to treat inflammation [1,2], and as a blood depurative [3]. Pharmacological studies demonstrated that the anti-inflammatory and antioxidant effects of $J$. paniculata were associated to the presence of flavonoids and other polyphenols [4]. Recently, we reported the in vivo anti-inflammatory properties of an aqueous fraction of the leaves of $J$. sellowii, that is in agreement with its popular use in Brazil [5].

Apart from the polyphenols identified in Jungia species, sesquiterpenoids with guaiane, guaiene, nortrixane, trixane (isocedrene), and cyperane scaffolds are also representative of this genus [6-9]. These terpenoids demonstrated a wide range of bioactivities [10-12], and hit compounds such as artemisinine, thapsigargin, and parthenolide are used nowadays for the treatment of malaria and cancer and have shown antileishmanial activities $[13,14]$.

About two million new cases of Leishmania infection are considered to occur every year in tropical countries including Brazil. Today no effective vaccine for the prevention of Leishmania diseases exist, whereas current chemotherapy is ineffective due to the high toxicity, the emergence of drug resistance, and the high cost of treatment, among others [15-17]. Consequently, infected people betake of medicinal plants as an alternative to provide treatment.

Plants also have an important role as a source of antitumoral agents, and several anticancer drugs currently in use are derived from natural sources. Natural products often have selective biological actions due to binding affinities for specific proteins, and have superior chemical diversity and complexity, and frequently have more advantageous ADME/T properties [18]

Compared to other chromatographic methods, centrifugal partition chromatography (CPC) is compatible with green chemistry criteria since it does not use any polluting solid support such as silica. Moreover, it allows the complete recovery of the injected extract without degradation and only requires a limited amount of organic solvents [19], and it turned to be a versatile method of separation for the isolation of glycosides [20,21].
Based on the above observation, our aims were to identify new metabolites from J. sellowii and assess their antileishmanial and cytotoxic effects. To the best of our knowledge, there are no reports dealing with the isolation and structure characterization of glycosylated sesquiterpene derivatives from Jungia sellowii.

\section{Results and Discussion CPC separation}

The aerial parts crude extract of Jungia sellowii was investigated using liquid-liquid partition and centrifugal partition chromatography (CPC), which is related to the counter-current chromatography (CCC) [22]. The chromatographic behavior of the butanol fraction of the leaves of J. sellowii was evaluated in six different biphasic systems consisting of different proportions of ethyl acetate (EtOAc)/ethanol $(\mathrm{EtOH}) / \mathrm{H}_{2} \mathrm{O}$ by using the shakeflask method [23] (Table 1). These trials considered the performance of the phase's separation and also the spots profile when monitored by TLC. Among them, the mixture of EtOAc/EtOH/ $\mathrm{H}_{2} \mathrm{O}(9: 2: 10, \mathrm{v} / \mathrm{v} / \mathrm{v})$ gave a better separation, and it was used in the CPC equipment (details described in the experimental section) from which three new glycosylated sesquiterpenes were achieved in a single run in less than two hours (Figure 1). The compounds were identified to be two trixanolides and one guaianedienone (Figure 2) and the partition coefficient calculated for compounds $\mathbf{1}$ (16.20), 2 (2.77) and 3 (13.51) (Figure 1).

\begin{tabular}{|c|c|c|c|}
\hline Condition & Ethyl acetate & Ethanol & Water \\
\hline 1 & 9 & 2 & 10 \\
\hline 2 & 8 & 2 & 10 \\
\hline 3 & 7 & 2 & 10 \\
\hline 4 & 9 & 1 & 10 \\
\hline 5 & 9 & 3 & 10 \\
\hline 6 & 8 & 3 & 10 \\
\hline
\end{tabular}

Sesquiterpenes were previously reported from the genus Jungia [6,7,24-26]. Nevertheless, no glycosylated sesquiterpenes (and sesquiterpene lactones) were previously found in this genus. $\mathrm{CPC}$ has been used in a semi-empirical mode [20] as a replacement of vacuum liquid chromatography (VLC) or reversed- 


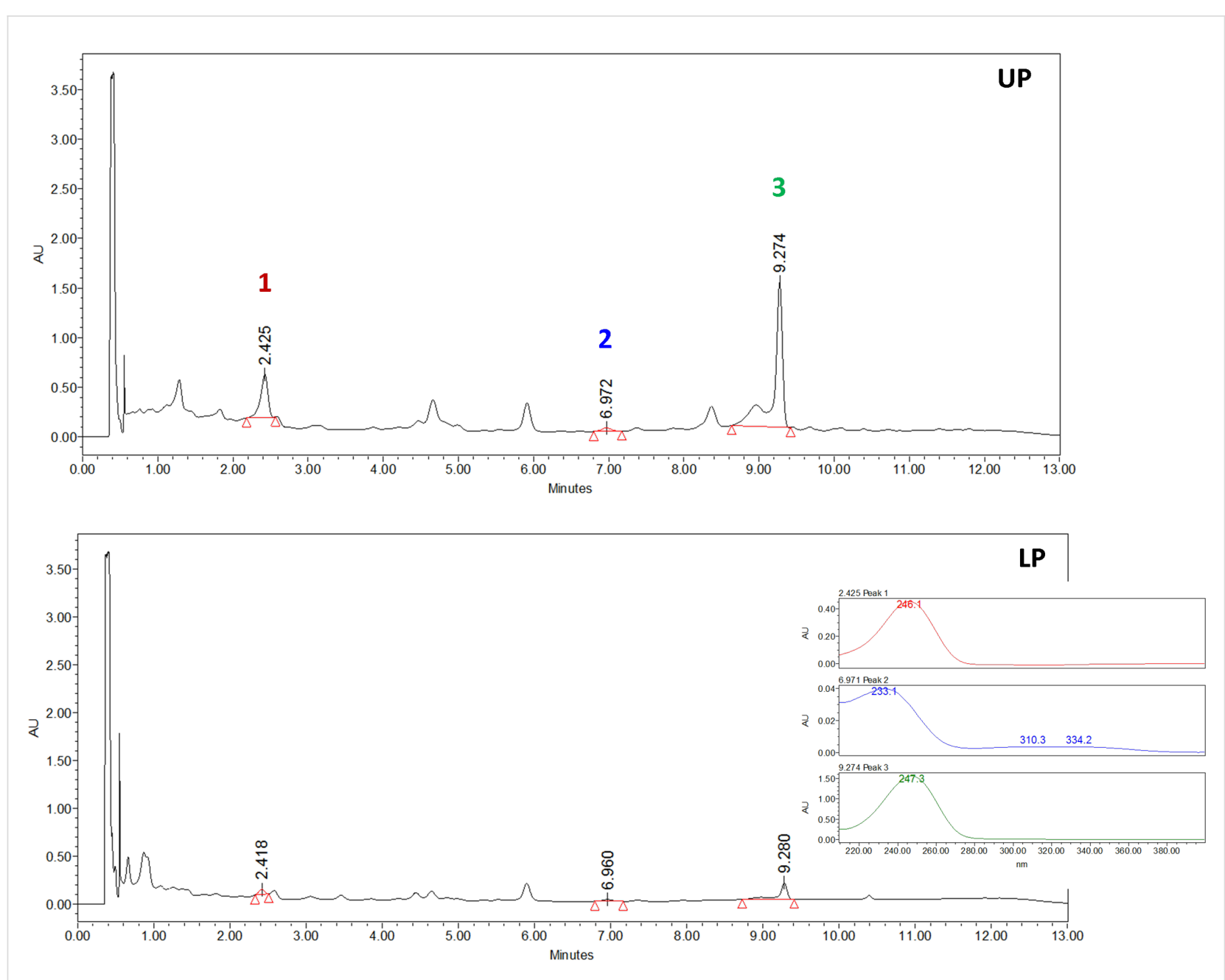

Figure 1: UPLC profile of the butanol fraction of the leaves of Jungia sellowii after shaking the flask with the selected biphasic system (details in the Experimental section). UP: upper phase (top chromatogram), LP: lower phase (bottom chromatogram). Detection at $242 \mathrm{~nm}$.
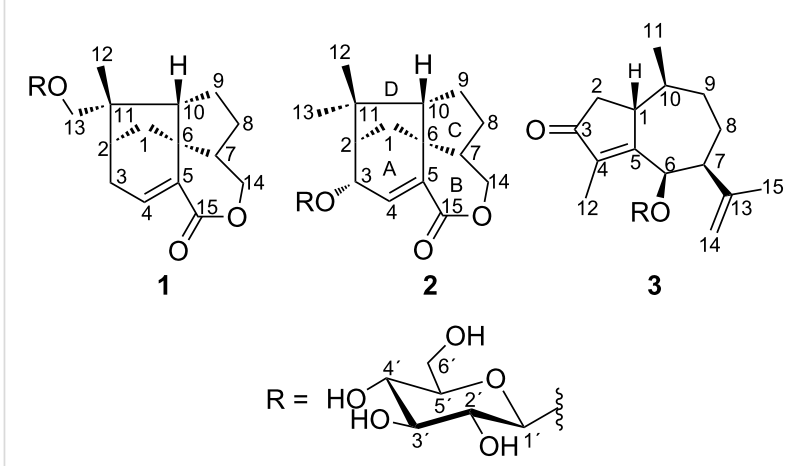

Figure 2: Structures of compounds 1-3.

phase medium pressure liquid chromatography (MPLC), permitting specially the isolation of several terpene glycosides [27], such as a geranyl disaccharide [28], natural [29,30], semisynthetic iridoid derivatives [31], and diterpene glycosides
[32]. This technique was for the first time used with Jungia extracts.

\section{Elucidation of the compounds}

Compound 1 was obtained as colorless gum. The molecular formula $\mathrm{C}_{21} \mathrm{H}_{30} \mathrm{O}_{8}$ was determined from its ESI-HRMS spectrum which gave the cationic ion peak $[\mathrm{M}+\mathrm{H}]^{+}$at $\mathrm{m} / z$ 411.1997 (calcd for 411.2019). The elemental composition indicated seven double bond equivalents. The ${ }^{13} \mathrm{C}$ NMR spectrum of 1 displayed 21 signals: one $\mathrm{CH}_{3}$ group, seven $\mathrm{CH}_{2}$ groups, nine $\mathrm{CH}$ groups and four quaternary carbons. The study of the HSQC NMR correlation map revealed that among the $\mathrm{CH}_{2}$ groups, three were oxygenated while the $\mathrm{CH}$ groups included one anomeric ( $\delta 4.28 / 104.7$, Table 2 and Table 3$)$, one olefin $(\delta$ $6.79 / 139.7)$, and four bearing oxygen $(\delta 3.20 / 75.0,3.38 / 78.0$, $3.32 / 71.8$, and 3.30/77.4). A sugar moiety was deduced mainly from HSQC and COSY correlations observed between the oxymethine groups, the hemi-acetal and one of the $\mathrm{CH}_{2} \mathrm{O}$ 


\begin{tabular}{|c|c|c|c|}
\hline \multirow[t]{2}{*}{ Position } & \multicolumn{3}{|c|}{ Aglycone } \\
\hline & 1 & 2 & 3 \\
\hline 1 & $1.66(\mathrm{~m}), 2.07(\mathrm{~m})$ & $\begin{array}{l}1.72(\mathrm{dd}, 4.4,11.5 \mathrm{~Hz}) \\
1.80(\mathrm{br} \mathrm{d}, 11.5 \mathrm{~Hz})\end{array}$ & $3.35(\mathrm{~m})$ \\
\hline 2 & $2.38(\mathrm{~m})$ & $2.17(\mathrm{~m})$ & $\begin{array}{l}1.96(\mathrm{~m}) \\
2.24(\mathrm{dd}, 7.2,18.4)\end{array}$ \\
\hline 3 & $2.44(\mathrm{t}, 3.6 \mathrm{~Hz})$ & $4.43(\mathrm{dd}, 2.1,4.1 \mathrm{~Hz})$ & - \\
\hline 4 & $6.79(\mathrm{t}, 3.6 \mathrm{~Hz})$ & $6.71(\mathrm{dd}, 1.5,4.1 \mathrm{~Hz})$ & - \\
\hline 5 & - & - & - \\
\hline 6 & - & - & $4.93(\mathrm{br} \mathrm{s})$ \\
\hline 7 & $2.11(\mathrm{~m})$ & $2.14(\mathrm{~m})$ & $1.97(\mathrm{~m})$ \\
\hline 8 & $1.58(\mathrm{~m}), 2.00(\mathrm{~m})$ & $1.71(\mathrm{~m}), 2.05(\mathrm{~m})$ & $1.09(\mathrm{~m}), 1.30(\mathrm{~m})$ \\
\hline 9 & $1.63(\mathrm{~m}), 1.69(\mathrm{~m})$ & $1.56(\mathrm{~m}), 1.67(\mathrm{~m})$ & $1.57(\mathrm{~m}), 2.02(\mathrm{~m})$ \\
\hline 10 & 2.12 (overlapped) & $1.90(\mathrm{~m})$ & $2.51(\mathrm{~m})$ \\
\hline 11 & - & - & - \\
\hline 12 & $1.12(\mathrm{~s})$ & $1.05(\mathrm{~s})$ & $1.91(\mathrm{br} \mathrm{s})$ \\
\hline 13 & $\begin{array}{l}3.39(\mathrm{~d}, 9.2 \mathrm{~Hz}) \\
3.82(\mathrm{~d}, 9.2 \mathrm{~Hz})\end{array}$ & $1.10(\mathrm{~s})$ & $4.82(\mathrm{~m}), 4.97(\mathrm{br} \mathrm{s})$ \\
\hline 14 & $4.04(\mathrm{dd}, 5.5,11.7 \mathrm{~Hz}), 4.17(\mathrm{dd}, 4.3,11.7 \mathrm{~Hz})$ & $\begin{array}{l}4.11(\mathrm{dd}, 4.9,11.7 \mathrm{~Hz}) \\
4.25(\mathrm{dd}, 4.2,11.7 \mathrm{~Hz})\end{array}$ & $0.93(\mathrm{~d}, 7.2 \mathrm{~Hz})$ \\
\hline 15 & - & - & $1.66(\mathrm{br} \mathrm{d}, 2.2 \mathrm{~Hz})$ \\
\hline \multicolumn{4}{|c|}{ Glucopyranosyl } \\
\hline $1^{\prime}$ & $4.28(\mathrm{~d}, 7.7 \mathrm{~Hz})$ & $4.47(\mathrm{~d}, 7.7 \mathrm{~Hz})$ & $4.39(\mathrm{~d}, 7.8 \mathrm{~Hz})$ \\
\hline $2^{\prime}$ & 3.20 (pseudo-t, $8.3 \mathrm{~Hz}$ ) & $3.16(\mathrm{dd}, 7.7,8.8 \mathrm{~Hz})$ & $3.27(\mathrm{~m})$ \\
\hline $3^{\prime}$ & $3.38(\mathrm{~m})$ & $3.38(\mathrm{~m})$ & $3.24(\mathrm{~m})$ \\
\hline $4^{\prime}$ & $3.32(\mathrm{~m})$ & $3.33(\mathrm{~m})$ & $3.33(\mathrm{~m})$ \\
\hline $5^{\prime}$ & $3.30(\mathrm{~m})$ & $3.33(\mathrm{~m})$ & $3.37(\mathrm{~m})$ \\
\hline $6^{\prime}$ & $\begin{array}{l}3.65(\mathrm{dd}, 5.0,11.5 \mathrm{~Hz}) \\
3.83(\mathrm{~m})\end{array}$ & $\begin{array}{l}3.66(\mathrm{dd}, 4.9,11.7 \mathrm{~Hz}) \\
3.83(\mathrm{dd}, 7.8,11.7 \mathrm{~Hz})\end{array}$ & $\begin{array}{l}3.55(\mathrm{dd}, 5.5,11.7 \mathrm{~Hz}) \\
3.69(\mathrm{dd}, 3.1,11.7 \mathrm{~Hz})\end{array}$ \\
\hline
\end{tabular}

$(\delta 3.65,3.83 / 63.0)$ groups. Furthermore, the quaternary carbons included an $\alpha, \beta$-unsaturated carbonyl ( $\delta 165.5)$, an olefinic carbon $(\delta 137.5)$ and two $\mathrm{sp}^{3}$ carbons ( $\delta 47.7$ and 53.8). Fifteen carbon shifts remained after the sugar deduction suggesting the aglycone to be a sesquiterpene [33]. Based on previous reports, the signals of a $\mathrm{CH}$ group at $\delta 2.12 / 65.2(\mathrm{C}-10)$ and a quaternary carbon at $\delta 53.8(\mathrm{C}-6)$ observed in the NMR spectra of compound 1 suggested a trixane scaffold for this secondary metabolite [34]. C-10 and C-6 are respectively shared by two and four strained rings in the trixane skeleton, explaining their downfield resonances. COSY correlations (Figure 3$)$ revealed from $\mathrm{H}-10(\delta 2.12)$ to $\mathrm{H}-9(\delta 1.63,1.69)$, H-9 to H-8 $(\delta 1.58$, $2.00), \mathrm{H}-8$ to $\mathrm{H}-7$ ( $\delta$ 2.11) which in turn correlated with $\mathrm{H}-14$ $(\delta 4.04,4.17)$ in addition to the HMBC correlations (Figure 3$)$ from $\mathrm{H}-10$ to $\mathrm{C}-6$ ( $\delta 53.8), \mathrm{H}-7$ to $\mathrm{C}-6$, and $\mathrm{H}-14$ to $\mathrm{C}-15$ ( $\delta$ 165.5) allowed to form the rings B and C. Moreover, C-6 had a long-range correlation with $\mathrm{H}-1(\delta 1.66,2.07)$ which in turn displayed a COSY contact with H-2 $(\delta 2.38)$. This latter also correlated with $\mathrm{H}-3(\delta 2.44)$ which showed a similar interaction with H-4 ( $\delta 6.79)$. The above correlations together with the long-range heteronuclear interactions between $\mathrm{H}-4$ and $\mathrm{C}-6$, as well as H-3, C-4 ( $\delta 139.7)$ and C-5 ( $\delta$ 137.5) allowed deducing the ring $\mathrm{A}$. The last ring was established from the HMBC correlations observed between the protons of Me-12 and carbons $\mathrm{C}-2$ ( $\delta 43.0), \mathrm{C}-10$ ( $\delta$ 65.2), C-11 ( $\delta 47.7)$, and C-13 ( $\delta$ 76.4). The sugar moiety was identified as glucopyranosyl by comparing its chemical shift with those formerly reported [35]. It was further attached to the aglycone at C-13 since $\mathrm{H}-13$ ( $\delta 3.39,3.82)$ correlated with the anomeric carbon (104.7). NOE correlations (Figure 4) usually found in the $\beta$-D-glucopyranosyl core were also revealed between the anomeric proton $\mathrm{H}-1$ ' $(\delta 4.28), \mathrm{H}-3$ ' ( $\delta 3.38)$, and H-5' ( $\delta 3.30)$. The relative configuration of the aglycone was tentatively determined based on NOESY contacts observed between H-12, H-10, and H-3. Similarly, H-13 unveiled the same interactions with $\mathrm{H}-1$ and $\mathrm{H}-9$ while $\mathrm{H}-14$ correlated with H-8 (Figure 4). In order to determine the absolute configuration of the compounds 1-3, ECD spectra prediction was used [36,37]. The absolute configuration of $\mathbf{1}$ was assigned as $2 R, 6 S, 7 R, 10 R$, and $11 S$ by ECD analysis supported by the theoretical calculation using time-dependent den- 
Table 3: ${ }^{13} \mathrm{C}$ NMR data [100 MHz, $\left(\mathrm{CD}_{3}\right)_{2} \mathrm{CO}$ of compounds $\mathbf{1 - 3}$.

\begin{tabular}{llll} 
Position & \multicolumn{3}{c}{ Aglycone } \\
\hline & $\mathbf{1}$ & $\mathbf{2}$ & $\mathbf{3}$ \\
\hline 1 & 39.5 & 35.7 & 44.6 \\
2 & 43.0 & 53.4 & 36.8 \\
3 & 32.3 & 74.9 & 208.5 \\
4 & 139.7 & 137.3 & 134.0 \\
5 & 137.5 & 139.5 & 177.8 \\
6 & 53.8 & 54.7 & 80.9 \\
7 & 40.3 & 40.5 & 52.3 \\
8 & 31.0 & 31.5 & 30.1 \\
9 & 25.9 & 27.0 & 29.2 \\
10 & 65.2 & 63.2 & 33.2 \\
11 & 47.7 & 40.1 & 149.3 \\
12 & 24.7 & 28.7 & 22.9 \\
13 & 76.4 & 28.4 & 110.9 \\
14 & 68.7 & 68.8 & 20.3 \\
15 & 165.5 & 165.6 & 7.4 \\
Glucopyranosyl $^{\prime}$ & & & \\
$1^{\prime}$ & 104.7 & 103.6 & 104.8 \\
$2^{\prime}$ & 75.0 & 74.9 & 74.8 \\
$3^{\prime}$ & 78.0 & 78.0 & 77.1 \\
$4^{\prime}$ & 71.8 & 71.7 & 70.9 \\
$5^{\prime}$ & 77.4 & 77.6 & 76.5 \\
$6^{\prime}$ & 63.0 & 63.0 & 62.1 \\
& & &
\end{tabular}

sity functional theory. Thus, two Cotton Effects (CE) from the $\mathrm{n} \rightarrow \pi^{*}$ transition of the $\alpha, \beta$-unsaturated lactone were revealed at 225 and $275 \mathrm{~nm}$ with alternative signs (Figure 5). The aforementioned data in conjunction to the absolute configuration previously reported for trixanolides [34], led to identify compound 1 as a new member of the trixane sesquiterpenoids. The trivial name jungioside A was assigned.

Compound 2 was obtained as a colourless gum. The molecular formula $\mathrm{C}_{21} \mathrm{H}_{30} \mathrm{O}_{8}$ was determined from its ESI-HRMS which gave the cationic ion peak $[\mathrm{M}+\mathrm{H}]^{+}$at $m / z 411.2013$ (calcd for 411.2013). The elemental composition was consistent with seven double bond equivalents. The NMR spectra of compound 2 displayed similar features as compound $\mathbf{1}$ except for the presence of one more $\mathrm{CH}_{3}$ group, an additional $\mathrm{CH}$ group and the absence of two $\mathrm{CH}_{2}$ groups. The presence of resonances at $\delta 54.7(\mathrm{C}-6)$ and $\delta 1.90 / 63.2(\mathrm{H}-10 / \mathrm{C}-10)$ suggested 2 to be also a trixane-type as its congener $\mathbf{1}[1,2]$. The sugar moiety was attached at C-3 based on COSY correlation (Figure 3 ) of H-4 $(\delta 6.71)$ and $\mathrm{H}-3(\delta 4.43)$ in addition to the long-range correlation observed in the HMBC spectrum (Figure 3 ) from $\mathrm{H}-3$ to the anomeric carbon $(\delta$ 103.6). The coupling constant of the anomeric proton $(J=7.7 \mathrm{~Hz})$ and the NOESY correlation of this latter with H-3' $(\delta 3.38)$ and $\mathrm{H}-5^{\prime}$ ( $\left.\delta 3.33\right)$ were consistent with $\beta$-D-glucopyranosyl moiety [38]. Besides, the stereochemistry of chiral centers in the aglycone was tentatively assigned as

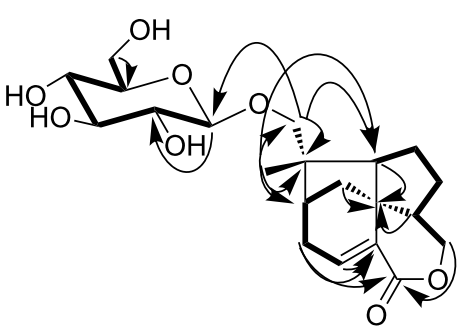

1

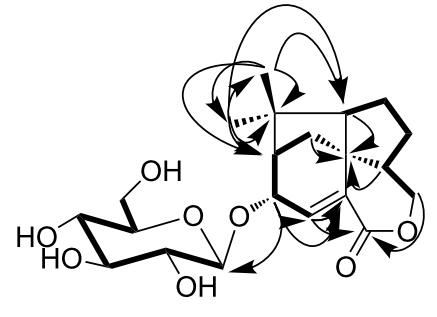

2

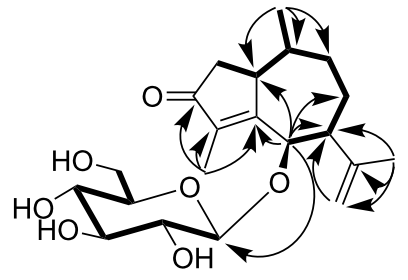

3

Bold: COSY, Arrow: HMBC

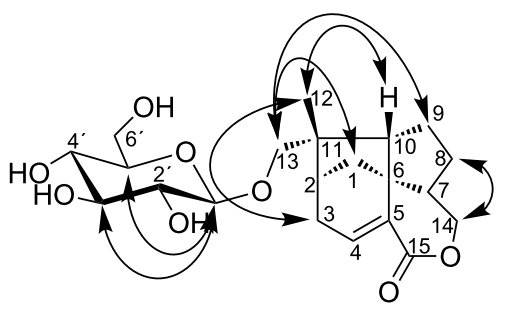

1

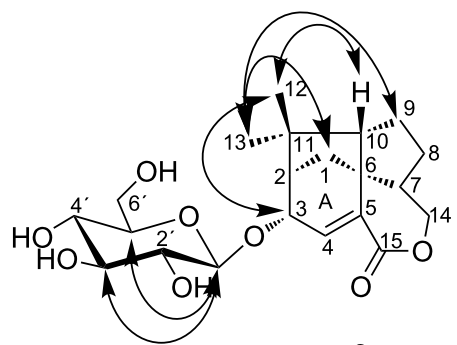

2

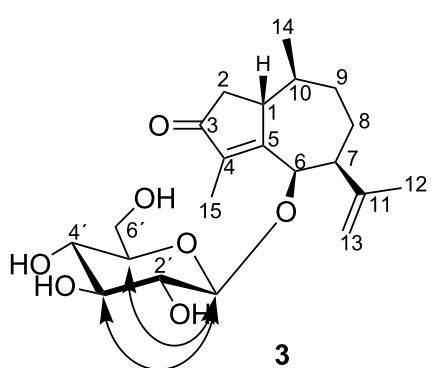

3

Figure 4: NOESY correlations of compounds 1-3. 


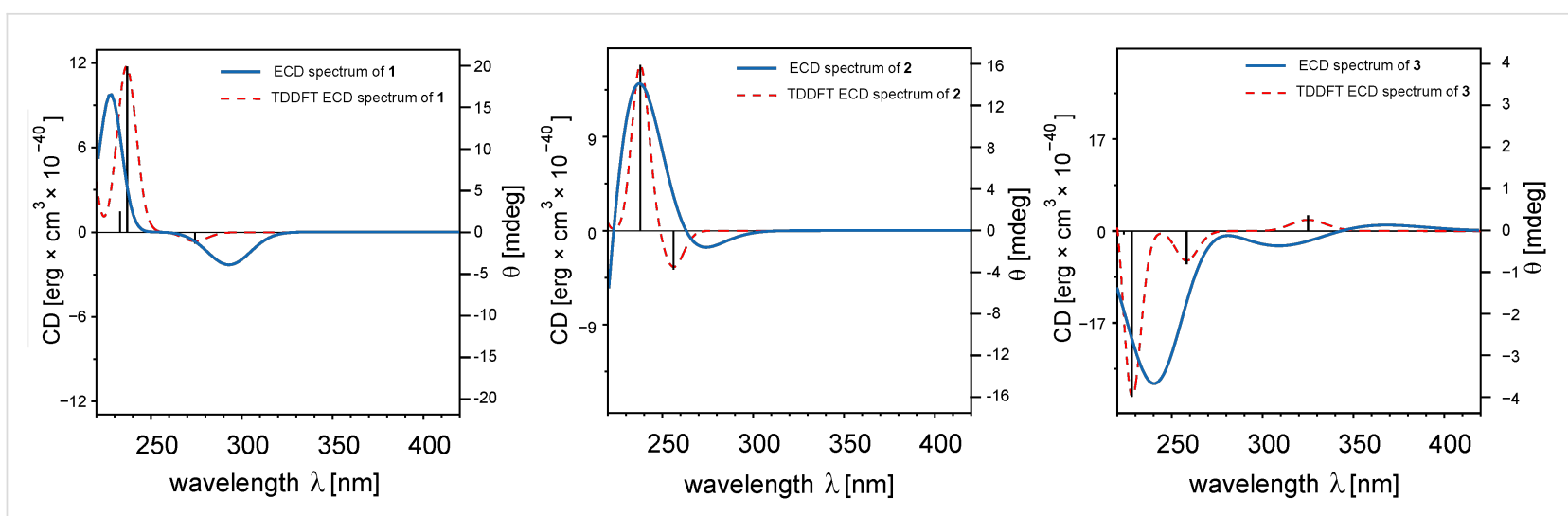

Figure 5: ECD spectra of compounds 1-3.

those previously reported for the trixane skeleton. Relative configurations of compound 2 turned to be similar as that of compound 1 since $\mathrm{H}-12(\delta 1.05)$ revealed NOE contact (Figure 4$)$ with $\mathrm{H}-3(\delta 4.43)$ and $\mathrm{H}-10(\delta 1.90)$ likewise, $\mathrm{H}-13(\delta 1.10)$ showed similar interactions with H-1 $(\delta 1.72)$ and H-9 $(\delta 1.56$, $1.67)$.

The absolute configuration of 2 was determined to be $2 R, 3 S$, $6 S, 7 R$, and $10 S$ by ECD analysis. As compound 1, two Cotton Effects (CE) from the $n \rightarrow \pi^{*}$ transition of the $\alpha, \beta$-unsaturated lactone were revealed at 225 and $275 \mathrm{~nm}$ with alternative signs (Figure 5). The complete assignment in conjunction to the data found in the literature led to identify compound $\mathbf{2}$ as new trixane congener (Figure 2). The trivial name jungioside B was given.

The NMR data of $\mathbf{3}$ revealed signals of a $\beta$-D-glucopyranosyl ( $\delta$ 4.39/104.8, 3.27/74.8, 3.24/77.1, 3.33/70.9, 3.37/76.5, 3.55 and 3.69/62.1) as found in the above-mentioned compounds and signals of fifteen carbons suggesting another sesquiterpene bearing a sugar moiety. The diagnostic of $2 \mathrm{D}$ experiments permitted to identify the aglycone as a guaiane-type sesquiterpene whose the structure was consistent with 6-hydroxyguaiane previously reported [39]. Moreover, the HMBC correlation (Figure 3) from the hydrogen at $\delta 4.93$ to the anomeric carbon ( $\delta$ 104.8) revealed the presence of an osidic bond. Thus, the molecular formula $\mathrm{C}_{21} \mathrm{H}_{32} \mathrm{O}_{7}$ was deduced from the aforementioned information in conjunction to the ESI-HRMS which gave the pseudo-molecular ion peak at $m / z 397.2239[\mathrm{M}+\mathrm{H}]^{+}$ (calcd. 397.2226). The elemental composition corresponded to six double bond equivalents. Some spatial correlations were observed in the NOESY spectrum from H-1 to H-14 and from H-6 to $\mathrm{H}-7$ consistent with the relative configuration reported the aglycone [39]. The absolute configuration of $\mathbf{3}$ was assigned as $1 R, 6 R, 7 S$, and $10 S$. Three CE's were observed on the experimental ECD spectrum at 240,305 and $350 \mathrm{~nm}$ due to the $\mathrm{n} \rightarrow \pi^{*}$ transition of the $\alpha, \beta$-unsaturated ketone. The foregoing data led to identify 3 as 6-hydroxyguaiane congener (Figure 2) and the trivial name guaianoside was given.

Trixane derivatives have recently been reported as antileishmanial metabolites [40], and on the basis of these results the butanol fraction from the areal parts crude extract as well as its isolated compounds (1-3) were evaluated for their leishmanicidal activity against $L$. donovani, $L$. infantum and $L$. amazonensis (promastigotes and intracellular amastigotes). The cytotoxicity of the butanol fraction in murine macrophages was found weak, with an $\mathrm{IC}_{50}$ value at $290 \mu \mathrm{g} / \mathrm{mL}$. However, the butanol fraction displayed activity against $L$. amazonensis intracellular amastigotes with an $\mathrm{IC}_{50}$ value of $100 \mu \mathrm{g} / \mathrm{mL}$. Except for compound 1 that exhibited a weak antileishmanial activity at $50 \mu \mathrm{M}$ (20\%) against L. amazonensis intracellular amastigotes, none of the other sesquiterpenes displayed antiparasitic activity.

Compounds 1-3 showed less than 50\% antiproliferative effect on leukemic cell lines HL60, JURKAT and REH at $15 \mu \mathrm{M}$.

\section{Conclusion}

The chemical study of the leaves of $J$. sellowii led to the isolation and characterization of three new sesquiterpene glycosides, including the first report of trixane lactone glycosides. Liquid-liquid partition and CPC proved to be a very useful technique for the investigation of polar extracts. Moreover, the commercial availability of industrial instruments enables scaleup to batch production for high-scale isolation. The CPC technique turned to be a versatile analytical tool leading to the purification and identification of new glycosylated sesquiterpenes including a rare skeleton (trixane). Only few of them were described from the genus Jungia along with polyacetylenes, coumarins and flavonoids [6,7,24-26]. Globally, the tested glycosylated sesquiterpenes displayed no or weak activity against Leishmania strains, and displayed no cytotoxici- 
ty against murine macrophages and the leukemic cancer cell lines.

\section{Experimental \\ Solvents, materials and instruments}

Ethanol for extraction and organic solvents for partitioning (hexane, dichloromethane, ethyl acetate, and butanol) as well as for CPC were pro-analysis grade (p.a.). Water was distilled from deionized water whereas $\mathrm{MeOH}$ and acetonitrile for UHPLC were of analytical grade (HPLC grade).

Merck precoated silica gel $60 \mathrm{~F}_{254}$ plates, $0.25 \mathrm{~mm}$ thickness, were used for analytical thin-layer chromatography. The visualization of spots on TLC plates was effected by exposure to UV $254 \mathrm{~nm}$ and by spraying with sulfuric vanillin solution at $30 \%$ and heating. The mobile phase used to monitor the method development and the fractions was composed by EtOAc/ $\mathrm{CH}_{2} \mathrm{O}_{2} /$ $\mathrm{AcOH} / \mathrm{H}_{2} \mathrm{O}$ (60:0.6:0.6:20). The 1D and 2D NMR experiments were recorded with Bruker AC-300 and Bruker Avance-400 spectrometers at $400 \mathrm{MHz}$ for ${ }^{1} \mathrm{H}$ and 2D NMR and at $75 \mathrm{MHz}$ for ${ }^{13} \mathrm{C}$ NMR. The spectra were recorded using deuterated solvents $\mathrm{CDCl}_{3}$ and $\mathrm{CD}_{3} \mathrm{OD}$. Chemical shifts $(\delta)$ are expressed in ppm with reference to the TMS signal $\left(\delta_{\mathrm{H}} / \delta_{\mathrm{C}} 0.0\right)$ and coupling constants are reported in Hz. The 2D NMR experiments (COSY, HSQC, HMBC, and NOESY) were performed using standard Bruker microprograms. UPLC-PDA analyses were performed on a Waters Acquity H UPLC quaternary system manager equipped with a Acquity sample manager and a PDA detector. Data were processed with Empower 3 software. CPC separation was performed on a SCPC-250+1000-B apparatus provided by Armen Instrument (Saint-Avé, France) fitted with a $1000 \mathrm{~mL}$ rotor containing 2016 twin-cells, equipped with a gradient pump and a $50 \mathrm{~mL}$ loop injection 6-way valve.

Electronic circular dichroism (ECD) spectra were recorded in acetonitrile using a Jasco XLC 3195CD detector.

\section{Plant material}

The leaves of J. sellowii Less. were collected in Rio Negrinho, Santa Catarina, Brazil, in March 2012. Plant identification was performed by the botanist Dr. Ademir Reis from the botany department at the Federal University of Santa Catarina, and a voucher specimen (RB number 537.991) is preserved in the Jardim Botanico do Rio de Janeiro, Brazil.

\section{Measurement of the partition coefficient ( $K$ value)}

First, the selected solvent system (EtOAc/EtOH/ $\mathrm{H}_{2} \mathrm{O}, 9: 2: 10$, $\mathrm{v} / \mathrm{v} / \mathrm{v}$ ) was prepared and equilibrated, then $1 \mathrm{~mL}$ of the upper phase and $1 \mathrm{~mL}$ of the lower phase were taken to a test tube and about $1 \mathrm{mg}$ sample was added into it. The test tube was shaken vigorously and allowed to settle for $5 \mathrm{~min}$. About $0.5 \mathrm{~mL}$ of upper and lower phases were taken into two vials and evaporated under nitrogen. The residues of each phase were dissolved in $1 \mathrm{~mL}$ of methanol and were then analyzed by UPLC (Figure 1). The $K$ value was expressed as the peak area of compounds in upper phase divided by that in the lower phase.

Chromatographic conditions employed for the peak area measurement were column Acquity UPLC BEH C18 $1.7 \mu \mathrm{m}(2.1 \times$ $50 \mathrm{~mm}$ ), with a flow rate of $0.3 \mathrm{~mL} / \mathrm{min}$ using gradient mode composed of formic acid $0.1 \%$ (A) and acetonitrile (B): starting $85 \%$ of $\mathrm{A}$, changing to $82 \%$ of $\mathrm{A}$ in $3 \mathrm{~min}$, to $78 \%$ of $\mathrm{A}$ in $5 \mathrm{~min}$, to $65 \%$ of A in $10 \mathrm{~min}$, returning to the initial conditions in $12 \mathrm{~min}$. The detection was done at a wave length of $242 \mathrm{~nm}$.

\section{Computational details (ECD)}

All calculations were conducted using Gaussian 09W [41]. After geometry optimization using density functional theory (DFT) at the B3LYP/6-311+g (d,p) level of theory. A check for imaginary frequencies was performed in order to confirm the presence of a real minimum. Calculations of the rotational strengths and excitation energies were realized using time dependent (TD) DFT at the same level of theory. ECD spectra were plotted using the SpecDis v1.61 software [42].

\section{Extraction, fractionation and isolation proce- dure}

Fresh leaves of $J$. sellowii $(1.8 \mathrm{~kg})$ were macerated in $3 \mathrm{~L}$ of $\mathrm{EtOH} / \mathrm{H}_{2} \mathrm{O}(1: 1)$ that after solvent removal furnished $40 \mathrm{~g}$ of crude extract. This crude extract was dissolved in $600 \mathrm{~mL}$ of cold water and partitioned with solvents of increasing polarity, giving hexane (hex, $0.4 \mathrm{~g}$ ), dichloromethane (DCM, $1 \mathrm{~g}$ ), EA $(0.6 \mathrm{~g})$ and $\mathrm{BuOH}(4.6 \mathrm{~g})$ fractions, together with the remaining aqueous fraction (lyophilized, $31.9 \mathrm{~g}$ ). CPC separation of the $\mathrm{BuOH}$ fraction ( $4 \mathrm{~g}$ ) was carried out in the optimized biphasic system composed by EtOAc/EtOH/ $\mathrm{H}_{2} \mathrm{O}, 9: 2: 10$, v/v/v, shaken in a separatory funnel and kept until the phase separation.

The separation was then conducted in isocratic ascending mode at room temperature, using the lower phase of the previously prepared mixture as stationary phase and the upper phase as mobile phase. The $1 \mathrm{~L}$ column was first filled with the lower phase in ascending mode at a flow-rate of $50 \mathrm{~mL} / \mathrm{min}$ at $500 \mathrm{rpm}$. Rotation speed was then set up at $1200 \mathrm{rpm}$ and the mobile phase pumped through the stationary phase at a flowrate of $25 \mathrm{~mL} / \mathrm{min}$ until equilibration. The retention volume was determined as $320 \mathrm{~mL}$.

The butanol fraction was injected after dissolution in $20 \mathrm{~mL}$ of a mixture 1:1 of the selected biphasic system. 70 fractions of $50 \mathrm{~mL}$ were collected in the ascending mode. After switching to 
descending mode, 20 additional fractions of $50 \mathrm{~mL}$ were collected. Extrusion process started after finishing collection of the tubes by pumping the stationary phase into the column at a flow rate of $25 \mathrm{~mL} / \mathrm{min}$. Fractions collected in the descending mode (tubes 70-90) did not lead to any interesting outcome. However, Fractions from the ascending mode were pooled together based on their TLC profile affording fractions A-G. Fractions B (96 mg), C (85 mg) and F (90 mg) provided a single spot on the TLC plate, resulting in the elucidated new glycosylated sesquiterpenoids $\mathbf{3}, \mathbf{2}$ and $\mathbf{1}$, respectively (Figure 2).

Compound 1: colourless gum; IR $\lambda_{\max }\left(\mathrm{cm}^{-1}\right): 3390.8,2924.2$, 1705.7, 1627.9, 1420.8, 1363.4, 1265.9, 1221.8, 1162.1, 1077.4, 1035.0; ESI-HRMS $m / z 411.1997\left[\mathrm{C}_{21} \mathrm{H}_{30} \mathrm{O}_{8}+\mathrm{H}\right]^{+}$(calcd. 411.2019), $821.3940[2 \mathrm{M}+\mathrm{H}]^{+}$. For ${ }^{1} \mathrm{H}$ and ${ }^{13} \mathrm{C}$ NMR data see Table 2 and Table 3.

Compound 2: colourless gum; IR $\lambda_{\max }\left(\mathrm{cm}^{-1}\right)$ : 3396.4, 2924.4, 2872.4, 1704.7, 1458.8, 1364.4, 1266.2, 1221.3, 1074.8, 1036.4; ESI-HRMS $m / z 411.2013\left[\mathrm{C}_{21} \mathrm{H}_{30} \mathrm{O}_{8}+\mathrm{H}\right]^{+}$(calcd. 411.2019), $433.1839[\mathrm{M}+\mathrm{Na}]^{+}$. For ${ }^{1} \mathrm{H}$ and ${ }^{13} \mathrm{C}$ NMR data see Table 2 and Table 3.

Compound 3: colourless gum; IR $\lambda_{\max }\left(\mathrm{cm}^{-1}\right)$ : 3376.4, 2938.0, 1688.2, 1080.5; ESI-HRMS $m / z 397.2239\left[\mathrm{C}_{21} \mathrm{H}_{32} \mathrm{O}_{7}+\mathrm{H}\right]^{+}$ (calcd. 397.2226), $793.4391[2 \mathrm{M}+\mathrm{H}]^{+}$. For ${ }^{1} \mathrm{H}$ and ${ }^{13} \mathrm{C} \mathrm{NMR}$ data see Table 2 and Table 3.

\section{Bioactivity tests}

\section{Evaluation of antileishmanial activity}

L. donovani (strain LG13, MHOM/ET/0000/HUSSEN), L. infantum (MHOM/GR/2002/GH12) and L. amazonensis (MPRO/BR/72/M1845) promastigotes and the murine macrophage J774 cell line (American Type Culture Collection, Manassas, VA) were cultured in RPMI 1640 (RPMI) medium, respectively, supplemented with $10 \%$ heat-inactivated fetal bovine serum, $10 \mathrm{mM}$ HEPES and antibiotics (penicillin/ streptomycin) as previously described at $26 \mathrm{C}$ [43]. The inhibitory activity of compounds was determined with the use of an MTT-based assay, the Alamar blue, as previously described [44]. The 50\% maximal inhibitory concentration $\left(\mathrm{IC}_{50}\right)$ was calculated using a nonlinear regression curve fit [45].

For evaluating the inhibitory activity of compounds against intracellular amastigotes, J774 macrophages were seeded into 96-well flat bottom plates at a density of $2 \times 10^{5}$ cells $/ \mathrm{mL}$ in $200 \mu \mathrm{L}$ RPMI and were left to adhere overnight at $37^{\circ} \mathrm{C}$ in $5 \%$ $\mathrm{CO}_{2} .24 \mathrm{~h}$ later macrophages were infected with stationary phase promastigotes at a ratio of 10 parasites per macrophage and incubated for a further $24 \mathrm{~h}$ at $37^{\circ} \mathrm{C}$ in $5 \% \mathrm{CO}_{2}$ as previously described [44].
All experiments were performed at least three independent times in triplicate.

\section{In vitro cytotoxicity against leukemic cells}

The cell lines used in this study were HL60 (Acute Promyelocytic Leukemia), JURKAT (Acute T cell Leukemia) and REH (Acute Lymphocytic Leukemia non-T; non-B). The cells were grown in plastic bottles $\left(75 \mathrm{~cm}^{3}\right.$ ) containing RPMI 1640 (Sigma R6504) medium supplemented with $10 \%$ fetal calf serum (Gibco 16000-044), 1\% penicillin (10000 IU/mL), and streptomycin $(10 \mathrm{mg} / \mathrm{mL})($ Gibco 15070$)$ at $37{ }^{\circ} \mathrm{C}$ in humidified air with $5 \% \mathrm{CO}_{2}$. The medium was changed every $48 \mathrm{~h}$.

The cytotoxicity of each compound in the cell lines indicated above was determined by the MTT (3-(4,5-dimethylthiazol-2yl)-2-5-diphenyltetrazolium bromide) assay [46]. The absorbance was read in a Synergy ELISA plate reader (Bio Tek Instruments, Highland Park, Winooski, USA) at $570 \mathrm{~nm}$. The results were expressed as percentage inhibition relative to control cells (considered as $100 \%$ ).

\section{Supporting Information}

\section{Supporting Information File 1}

NMR and MS spectra of compounds 1-3.

[http://www.beilstein-journals.org/bjoc/content/

supplementary/1860-5397-12-68-S1.pdf]

\section{Acknowledgements}

The authors thank the FP7-PEOPLE-2010-IRSES Marie Curie Actions, program "ChemBioFight', (exploring CHEMical BIOdiversity with innovative approaches for FIGHTing Chagas and leishmaniasis, grant number 269031) for financial support. Prof. A.-L. Skaltsounis and Dr. Maria Halabalaki are gratefully acknowledged for the management of the program. The authors declare no conflict of interest.

\section{References}

1. Hammond, G. B.; Fernández, I. D.; Villegas, L. F.; Vaisberg, A. J. J. Ethnopharmacol. 1998, 61, 17-30. doi:10.1016/S0378-8741(98)00009-9

2. Rojas, R.; Bustamante, B.; Bauer, J.; Fernández, I.; Albán, J.; Lock, O. J. Ethnopharmacol. 2003, 88, 199-204. doi:10.1016/S0378-8741(03)00212-5

3. Goleniowski, M. E.; Bongiovanni, G. A.; Palacio, L.; Nuñez, C. O.; Cantero, J. J. J. Ethnopharmacol. 2006, 107, 324-341. doi:10.1016/j.jep.2006.07.026

4. Casado, R.; Landa, A.; Calvo, J. J.; del Carmen Terencio, M.; Calvo, M. I. Pharm. Biol. 2010, 48, 897-905. doi:10.3109/13880200903311128 
5. Nader, M.; Vicente, G.; da Rosa, J. S.; Lima, T. C.; Barbosa, A. M.; Santos, A. D. C.; Barison, A.; Dalmarco, E. M.; Biavatti, M. W.; Fröde, T. S. Inflammopharmacology 2014, 22, 351-365. doi:10.1007/s10787-014-0210-3

6. Bohlmann, F.; Zdero, C. Phytochemistry 1977, 16, 239-242. doi:10.1016/S0031-9422(00)86793-X

7. Bohlmann, F.; Zdero, C. Chem. Ber. 1979, 112, 427-434. doi:10.1002/cber.19791120205

8. Ybarra, M. I.; Catalán, C. A. N.; Díaz, J. G.; Herz, W. Phytochemistry 1992, 31, 3627-3629. doi:10.1016/0031-9422(92)83741-G

9. Bohlmann, F.; Zdero, C.; King, R. M.; Robinson, H. Phytochemistry 1983, 22, 1201-1206. doi:10.1016/0031-9422(83)80222-2

10. Doan, N. T. Q.; Paulsen, E. S.; Sehgal, P.; Møller, J. V.; Nissen, P.; Denmeade, S. R.; Isaacs, J. T.; Dionne, C. A.; Christensen, S. B. Steroids 2015, 97, 2-7. doi:10.1016/j.steroids.2014.07.009

11. Edikpo, N.; Ghasi, S.; Elias, A.; Oguanobi, N. Mol. Cell. Pharmacol. 2013, 5, 75-89.

12. Ghantous, A.; Gali-Muhtasib, H.; Vuorela, H.; Saliba, N. A.; Darwiche, N. Drug Discovery Today 2010, 15, 668-678. doi:10.1016/j.drudis.2010.06.002

13. Tiuman, T. S.; Ueda-Nakamura, T.; Alonso, A.; Nakamura, C. V. BMC Microbiol. 2014, 14, No. 152. doi:10.1186/1471-2180-14-152

14. Odonne, G.; Herbette, G.; Eparvier, V.; Bourdy, G.; Rojas, R.; Sauvain, M.; Stien, D. J. Ethnopharmacol. 2011, 137, 875-879. doi:10.1016/j.jep.2011.07.008

15. Croft, S. L.; Olliaro, P. Clin. Microbiol. Infect. 2011, 17, 1478-1483. doi:10.1111/j.1469-0691.2011.03630.x

16. Croft, S. L.; Sundar, S.; Fairlamb, A. H. Clin. Microbiol. Rev. 2006, 19, 111-126. doi:10.1128/CMR.19.1.111-126.2006

17. Goto, H.; Lindoso, J. A. L. Expert Rev. Anti-Infect. Ther. 2010, 8, 419-433. doi:10.1586/eri.10.19

18. Atanasov, A. G.; Waltenberger, B.; Pferschy-Wenzig, E.-M.; Linder, T.; Wawrosch, C.; Uhrin, P.; Temml, V.; Wang, L.; Schwaiger, S.; Heiss, E. H.; Rollinger, J. M.; Schuster, D.; Breuss, J. M.; Bochkov, V.; Mihovilovic, M. D.; Kopp, B.; Bauer, R.; Dirsch, V. M.; Stuppner, H. Biotechnol. Adv. 2015, 33, 1582-1614. doi:10.1016/j.biotechadv.2015.08.001

19. Berthod, A. J. Liq. Chromatogr. Relat. Technol. 2007, 30, 1447-1463. doi:10.1080/10826070701277067

20. Wang, J.; Liu, C.-m.; Li, L.; Bai, H.-I. Phytochem. Anal. 2011, 22, 263-267. doi:10.1002/pca.1274

21. Wang, Y.; Guan, S.-h.; Feng, R.-h.; Zhang, J.-x.; Li, Q.; Chen, X.-h.; Bi, K.-s.; Guo, D.-a. Phytochem. Anal. 2013, 24, 671-676. doi:10.1002/pca.2453

22. Ito, Y. J. Chromatogr. A 2014, 1372, 128-132. doi:10.1016/j.chroma.2014.09.033

23. Berthod, A.; Carda-Broch, S. J. Chromatogr. A 2004, 1037, 3-14. doi:10.1016/j.chroma.2004.01.001

24. Bohlmann, F.; Zdero, C.; Le Van, N. Phytochemistry 1979, 18, 99-102. doi:10.1016/S0031-9422(00)90922-1

25. Bohlmann, F.; Zdero, C.; King, R. M.; Robinson, H. Planta Med. 1984, 50, 190-191. doi:10.1055/s-2007-969670

26. D'Agostino, M.; Senatore, F.; De Feo, V.; De Simone, F. Fitoterapia 1995, 66, 283-284.

27. Skalicka-Woźniak, K.; Garrard, I. Phytochem. Rev. 2014, 13, 547-572. doi:10.1007/s11101-014-9348-2

28. Mudge, E.; Lopes-Lutz, D.; Brown, P. N.; Schieber, A. Phytochem. Anal. 2013, 24, 129-134. doi:10.1002/pca.2391

29. Kim, C. Y.; Kim, J. Phytochem. Anal. 2007, 18, 115-117. doi:10.1002/pca.958
30. Yue, H.-L.; Zhao, X.-H.; Wang, Q.-L.; Tao, Y.-D J. Chromatogr. B: Anal. Technol. Biomed. Life Sci. 2013, 936, 57-62. doi:10.1016/j.jchromb.2013.08.007

31. Marković, D.; Barboux, C.; de Chou, Y. S.; Bettach, J.; Grougnet, R.; Deguin, B. RSC Adv. 2014, 4, 63254-63259. doi:10.1039/C4RA12141D

32. He, S.; Li, S.; Yang, J.; Ye, H.; Zhong, S.; Song, H.; Zhang, Y.; Peng, C.; Peng, A.; Chen, L. J. Chromatogr. A 2012, 1235, 34-38. doi:10.1016/j.chroma.2012.01.040

33. De Riscala, E. C.; Catalan, C. A. N.; Sosa, V. E.; Gutiérrez, A. B.; Herz, W. Phytochemistry 1988, 27, 2343-2346. doi:10.1016/0031-9422(88)80157-2

34. Kotowicz, C.; Hernández, L. R.; Cerda-Garcia-Rojas, C. M.; Villecco, M. B.; Catalán, C. A. N.; Joseph-Nathan, P. J. Nat. Prod. 2001, 64, 1326-1331. doi:10.1021/np010191z

35. Michalska, K.; Szneler, E.; Kisiel, W. Magn. Reson. Chem. 2015, 54, 175-177. doi:10.1002/mrc.4358

36. Bondu, S.; Genta-Jouve, G.; Leirós, M.; Vale, C.; Guigonis, J.-M.; Botana, L. M.; Thomas, O. P. RSC Adv. 2012, 2, 2828-2835. doi:10.1039/c2ra00045h

37. Genta-Jouve, G.; Weinberg, L.; Cocandeau, V.; Maestro, Y.; Thomas, O. P.; Holderith, S. Chirality 2013, 25, 180-184. doi:10.1002/chir.22129

38. Hua, Y.; Zhou, J.; Chen, C. X. Chin. Chem. Lett. 2007, 18, 73-75. doi:10.1016/j.cclet.2006.11.026

39. Silva, M.; Wiesenfeld, A.; Sammes, P. G.; Tyler, T. W. Phytochemistry 1977, 16, 379-385. doi:10.1016/0031-9422(77)80069-1

40. Maldonado, E. M.; Salamanca, E.; Giménez, A.; Saavedra, G.; Sterner, O. Phytochem. Lett. 2014, 10, 281-286. doi:10.1016/j.phytol.2014.10.017

41. Gaussian 09; Gaussian, Inc.: Wallingford, CT, USA, 2009.

42. Bruhn, T.; Schaumlöffel, A.; Hemberger, Y.; Bringmann, G. Chirality 2013, 25, 243-249. doi:10.1002/chir.22138

43. Alexandratos, A.; Clos, J.; Samiotaki, M.; Efstathiou, A.; Panayotou, G.; Soteriadou, K.; Smirlis, D. Mol. Microbiol. 2013, 88, 1015-1031. doi:10.1111/mmi.12240

44. Efstathiou, A.; Gaboriaud-Kolar, N.; Smirlis, D.; Myrianthopoulos, V.; Vougogiannopoulou, K.; Alexandratos, A.; Kritsanida, M.; Mikros, E.; Soteriadou, K.; Skaltsounis, A.-L. Parasites Vectors 2014, 7, No. 234 doi:10.1186/1756-3305-7-234

45. Oliveiro Costa, J. F.; Kiperstok, A. C.; Pereira de Lima David, J.; David, J. M.; Giulietti, A. M.; Paganucci de Queiroz, L.; dos Santos, R. R.; Soares, M. B. P. Fitoterapia 2007, 78, 510-514. doi:10.1016/j.fitote.2007.05.005

46. Mosmann, T. J. Immunol. Methods 1983, 65, 55-63. doi:10.1016/0022-1759(83)90303-4 


\section{License and Terms}

This is an Open Access article under the terms of the Creative Commons Attribution License

(http://creativecommons.org/licenses/by/2.0), which permits unrestricted use, distribution, and reproduction in any medium, provided the original work is properly cited.

The license is subject to the Beilstein Journal of Organic Chemistry terms and conditions:

(http://www.beilstein-journals.org/bjoc)

The definitive version of this article is the electronic one which can be found at:

doi:10.3762/bjoc. 12.68 